\title{
Theofilos
}

A Nordic open access journal in Theology, Philosophy and Culture

Published by NLA University College - in partnership with Johannelund School of Theology

Available at www.theofilos.no

\section{Donald Trump - stöd, kritik och kulturkamp}

\author{
Kjell O. Lejon \\ Professor i religionsvetenskap, Linköpings universitet \\ Vice-rektor, Johannelunds teologiska högskola, Uppsala \\ kjell.o.lejon@liu.se
}

\section{Inledning}

Under flera års tid har ett centrum för svensk mediabevakning varit Donald Trump, först som presidentkandidat, sedan som president, men även nu efter det att han lämnat presidentämbetet. Trots att han ifrågasatts i mycket, lade över 74,2 miljoner amerikaner (46,8\%) sin röst på honom i presidentvalet den 6 november 2020. Många av dessa var kristna republikaner. En hel del beslut som tagits av Trumpadministrationen, både $\mathrm{i}$ inrikes- och utrikespolitiska ärenden, har mötts med stort gillande i denna grupp. Men det finns en bredare bas. Till en stor del beror det på att många i Mellanvästern och Södern känner en distans till eller rentav aversion mot - "etablissemanget" i Washington DC, som man menar leder landet i fel riktning och som inte lyssnar på "vanligt" folk. En del har känt sympati för Trump som en orädd, framgångsrik, frispråkig, högprofilerad och av donatorer oberoende person. När han tillträdde hade han ingen erfarenhet av politiskt arbete, även om han en gång tidigare ställt upp som presidentkandidat (i The Reform Party, grundat 1995 av Ross Perot). Var det inte en orädd, om än bufflig, outsider som behövdes, tycktes många undra inför valet 2016? En del har sett positivt på hans attacker på "vänsterliberal media". Debatten om politisk korrekthet och "fake news" tog fart. Att Trump skulle väljas till president betvivlades in i det sista, eftersom valundersökningarna under hela 2016 pekade på att stödet för Hillary Clinton skulle föra henne till seger. Om inte coronapandemin genom "the China virus" slagit hårt mot det amerikanska folket och den amerikanska ekonomin hade Trump förmodligen blivit omvald 2020. (Redan i slutet av maj hade viruset krävt över 100000 människors liv och drygt 40 miljoner var arbetslösa - i jämförelse med 10 miljoner i januari.)

Trump har onekligen varit kontroversiell - och är så fortsatt. Ifrågasättandet har gällt tidigare affärsliv, hans karaktärsdrag och självbild och den världsuppfattning som emellanåt framträtt. En rad uttalanden och beslut har rönt skarp kritik, exempelvis vid uppmärksammade raskonflikter, efter polisvåld och när det gällt miljö- och immigrationspolitik. Vi har också sett en häpnadsväckande omsättning av personal inom administration och kabinett. "America first"-policyn kritiserades inte minst internationellt, men även frågan om USA skulle kunna köpa Grönland och murbygget vid gränsen mot Mexiko (som för övrigt startade långt innan Trump blev president; redan 1990 påbörjades bygget av ett gränsskydd vid gränsen mellan San Diego och Tijuana). I december 2019 tillkom dessutom en första riksrättsprocess mot Trump, sedan händelserna efter valet i november 2020, med Trumps förnekande av Bidens valvinst, den våldsamma demonstrationsattacken mot Kapitolium den 6 januari 2021 och en därpå följande andra riksrättsprocess. 


\section{En förstärkt polarisering med rötter i en kulturkamp}

Några pekar på att konsekvenserna av Trumps sammantagna politiska insats resulterat i drastiskt ökad polarisering i USA. Polariseringen har naturligtvis ökat, men polariseringsprocessen är flera decennier gammal och har djupa ideologiska förtecken. I denna har det demokratiska partiet alltmer gått i liberal och sekulär riktning, medan det republikanska partiet, inte minst sedan Reagans tid som president, i både partiprogram och framtoning allt tydligare förklarat sig stå för en socialkonservativ hållning med tydlig koppling till traditionell amerikansk bibelbaserad kristendom. I denna har mer traditionella evangelikala och romerska katoliker exempelvis mötts $i$ en gemensam syn på abortproblematiken och samkönade äktenskap. Enkelt uttryckt skulle man kunna säga att det handlar om en kultur- och identitetskamp, om USA tydligare skall anamma en "eurosekulär" hållning eller stå fast vid en traditionell betoning av nationens motto, "In God We Trust", och trohetsedens (The Pledge of Allegiance) "One nation under God".

Många röstade alltså på Trump (eller i vart fall republikanskt, även om de var kritiska mot personen Trump) såväl 2016 som 2020. En hel del kommentatorer och journalister, också i Sverige, har valt att "dumförklara" och avfärda alla "Trumpväljare". Men så enkelt bör man inte se på saken, utan snarare problematisera det större skeendet - som är större än Trump och hans presidentperiod och som även har europeisk bäring. Vidare bör vi fråga oss vilken information som kommer oss till del? Är den färgad? $\mathrm{Nu}$ är Trump onekligen ett särfall bland amerikanska presidenter, men det finns exempel på att man i svensk press framhåller och positivt presenterar demokratiska företrädare (såsom Bill Clinton, Barack Obama och Joe Biden), medan man i mer negativ dager beskriver republikanska företrädare, även presidenter. (Även osaklig kritik kan flöda när det gäller de senare, såsom att Ronald Reagan beskrevs som en "B-skådis", Gerald Ford som en som inte kunde tugga tuggummi och gå i trappor samtidigt, George H.W. Bush som en "färglös" politiker som fötts med en "silversked i munnen", och George W. Bush som "en lite korkad och farlig krigshetsare".) Förmodligen beror det till del på att den politiska igenkänningen är större när det gäller de demokratiska företrädarna.

\section{Trump och tron}

Donald Trump är av tysk-skotsk härkomst. Farföräldrarna var tyskfödda lutherska immigranter. Fadern Fred var sträng och krävande och hade stora förväntningar på sina barn. De skulle lyckas. I en biografi kopplas faderns hållning till protestantisk arbetsetik. På moderns sida kom man från Yttre Hebriderna på skotska västkusten och stod i presbyteriansk tradition. På söndagarna gick familjen i First Presbyterian Church at Jamaica, Queens, New York. Trump, som konfirmerades i denna kyrka, har senare förklarat: "Jag är välsignad med att ha blivit uppfostrad i ett kyrkligt hem.” Föräldrarna blev senare medlemmar i Marble Collegiate Church på Manhattan, i vilken även sonen Donald emellanåt kunde ses som besökare. Denna kyrka leddes av Norman Vincent Peale (1898-1993), som för övrigt var god vän med Richard Nixon. Kyrkan stod i Dutch Reformed tradition. Peale nådde berömmelse genom sitt författarskap, inte minst genom boken The Power of Positive Thinking (1955), som såldes i upp mot 20 miljoner exemplar och även finns i svensk översättning (Var positiv. Lev lycklig). Peale 
vigde Donald och Ivana Trump (Trumps första hustru) 1977 och han var den pastor Trump under presidentvalkampanjen 2016 relaterade till som sin ungdoms pastor. Trump har lovordat The Power of Positive Thinking och onekligen rimmar bokens tankar, såsom att "tro på dig själv och allt du gör" och "formulera i din tanke en mental bild av dig själv som en som lyckas", med det vi hört Trump uttala.

Politiskt har Trump skiftat i sitt stöd. När det gäller tron är Trump enligt egen utsago en bekännare av den kristna tron. Under lång tid har han kallat sig presbyterian, men förklarade i en intervju med Religion News Service i oktober 2020 att han blivit en samfundsoberoende ("nondenominational”) kristen. Möjligen kan han ha påverkats av Paula White-Cain, som fungerat som ordförande i en evangelikal rådgivningsgrupp kopplad till Trumps administration och som benämnts Trumps andliga rådgivare. Hon deltog med en bön vid Trumps installationshögtid i januari 2017 och i maj 2019 utnämndes hon till rådgivare vid The White House Faith and Opportunity Initiative, etablerat genom en exekutiv order (No.13831) den 3 maj 2018 och inordnat i The Office of Public Liaison. WhiteCain var tidigare pastor i en "non-denominational" megakyrka (New Destiny Christian Center) i Apopka, Florida.

I Trumps bok Great Again (2016) kan man läsa: "Jag tror att folk blir chockade när de förstår att jag är en kristen, att jag är en religiös person ... Jag går till kyrkan, jag älskar Gud, och jag älskar att ha en relation med Honom." Därför uppmärksammades hans uttalande under valkampanjen 2016 om att han inte var säker på om han någon gång bett Gud om förlåtelse. Han sade att han är en hederlig person som försöker leva sitt liv så att han inte behöver be Gud om förlåtelse. När något gått fel försöker han rätta till detta och "involverar inte Gud". Han tar, enligt egen utsago, ofta emot nattvarden. När han "drink my little wine ... and have my little cracker" upplever han att det renar honom.

Under resans gång har skarp kritik mot Trump infunnits även från evangelikalt håll, såsom av teologiprofessorn Michael Horton, som kommenterade Trumps koppling till Peale och citerade Adlai Stevensons svåröversatta ordlek: "Speaking as a Christian, I find Paul appealing and Peale appalling”. Vi återkommer till kritiken och ser först på stödet för Trump i kristna grupper.

\section{Trump och stödet bland kristna}

Trump förstod tidigt att han behövde räcka ut handen till kristna väljare, inte minst till den evangelikalt kristna kärngruppen i det republikanska partiet. Redan i maj 2015 förklarade Trump: "Tro mig, om jag ställer upp och vinner kommer jag att bli den främste representanten för de kristna som de haft på länge." Han fann emellertid i detta skede inget större gehör bland de evangelikala. Endast 5\% av de evangelikala pastorerna var positivt inställda till honom i början av detta år. De flesta evangelikala väljarna stödde istället andra kandidater, såsom Ted Cruz eller Marcio Rubio.

I sammanhanget bör noteras att "de evangelikala" inte är en enhetlig grupp utan består av en rad olika grupper med olika inriktning, även politiskt. De som man kanske oftast tänker på är de vita evangelikala - av vilka fyra av fem röstade på Trump, såväl 2016 som 2020. Men några är entydigt demokrater, såsom Jimmy Carter och Jim Wallis; andra är "svarta evangelikala", som övervägande röstar demokratiskt. Fler undergrupper finns - 
långt ifrån alla är så kallade "högerkristna”. Tidigt stöd fick Trump främst från s.k. "entreprenörs-evangelikaler" och "kulturella evangelikaler", men de var två mindre grupper av totalt minst sju-åtta grupper evangelikala. När primärvalen var över stod Trump emellertid ensam kvar på den republikanska sidan och i valet mellan honom och den politiska elitens Hillary Clinton blev det för många inte svårt att välja sida, till förmån för Trump. Det bör noteras att många i 2016 var mer emot Clinton än för Trump.

I sitt installationstal kopplade Trump amerikanskt ihop patriotism och kristen tro: "När du öppnar ditt hjärta för patriotism, finns det ingen plats för fördomar. Bibeln lär oss hur bra och behagligt det är när Guds folk lever tillsammans i endräkt”. Fyra pastorer, en romersk-katolsk ärkebiskop och en rabbin deltog vid installationshögtiden. Tidigare på dagen hade Trump deltagit i en privat morgongudstjänst i St. John's Episcopal Church (samma kyrka invid den numera berömda bilden på Trump hållande i en stor Bibel togs den 1 juni 2020, under runtomkring pågående demonstrationer mot polisbrutalitet efter George Floydhändelsen den 25 maj i Minneapolis. Det med kyrkan sammanbyggda församlingshuset, som man kunde se på bilden, hade natten innan brandskadats under de pågående protesterna. Trumps sätt att agera kritiserades från flera håll, även av personal i St. John's.)

Oavsett hur vi ser på Trump kom han under sin presidentperiod att vinna väljare av flera skäl. Det gällde exempelvis en tydlig "pro-life"-hållning; han varnade i samband med detta för en annars rådande "dödens kultur". Nämnas kan att den negativa inställning som många republikaner haft och fortsatt har till "Obamacare" bottnar i frågor om påtvingat till- handahållande av preventivmedel, om abort och samvetsfrihet. Detta senare problemkomplex nämns knappast alls i svensk media.

I många socialkonservativa kristna kretsar såg man vidare positivt på flera av Trumps val av medarbetare. Många uppfattade också det republikanska partiets val av vicepresident, Mike Pence, som en garant för en viss stabilitet inom administrationen utifrån kristen grund.

Bland de beslut som många kristna med mer traditionell hållning sympatiserat med under Trumps presidentperiod kan följande lite mer samlat nämnas:

- Trump lyfte fram fostrets rätt till liv och därför fattade han en rad beslut om att inte stödja abortverksamhet (abortrådgivning och aborter) med federala medel (som Obama gjort och som Biden nu åter gör),

- Trump deltog personligen i det årliga "March-for-Life"-samlingen i Washington DC den 24 februari 2020,

- Trump utnämnde socialkonservativa kristna till medlemmar i sitt kabinett, såsom Ben Carson (bostads- och landsbygdsminister) och Betsy DeVos (utbildningsminister),

- Trump utnämnde i författningsfrågor konservativa domare till Högsta domstolen (Neil McGill Gorsuch, Brett Michael Kavanaugh och Amy Coney Barret),

- Trump har även utnämnt en lång rad i författningsfrågor konservativa domare i lägre instanser och specialdomstolar,

- HBTQ-rörelsen inte haft något större inflytande på politiken och ingen HBTQ-månad utropades, såsom under Obama,

- Trump har allmänt uttryckt ett tydligt stöd för Israel. Detta stöd fick även 
konkreta uttryck, till exempel genom:

o erkännandet av Golanhöjderna som israeliskt landområde,

o erkännandet av Jerusalem som israelisk huvudstad,

o flytten av den amerikanska ambassaden från Tel Aviv till Jerusalem,

o Trump var den förste amerikanske presidenten som besökt Västra muren/ Klagomuren i Jerusalem,

o Trumps administration arbetade fram fredsavtal mellan några arabstater (till exempel Förenade Arabemiraten) och Israel, vilket utrikespolitiskt får anses vara en anmärkningsvärd prestation, ${ }^{1}$

- Trump har de facto inte startat något krig,

- Trump har ofta betonat sitt stöd för förföljda kristna runt om i världen och påtalat detta för statschefer/presidenter,

- Trump drev på frigivningen av ett par fängslade pastorer (en Nordkorea och en i Turkiet),

- Trump och hans administration har agerat för (enskildas och yrkesgruppers) rätt till samvetsfrihet,

- Trump har fastställt direktiv för att stoppa trakasserier av judar i amerikanska skolor.

Mer skulle här kunna nämnas som uppskattats av många kristna i USA och som därför ledde till att de röstade på Trump i valet 2020. I vissa kretsar har man dessutom lyft fram en kung "Kyros-parallell”, det vill säga att man jämfört Trump med den i Bibeln omtalade kung Kyros, vilken bottnar i en tolkning att båda ledarna, utan att de själva behöver vara medvetna om det (Kyros kände enligt bibeltexten inte Gud), fungerar som ett "verktyg" i Guds hand. Andra har jäm- fört Trump med kung David, en hjälte som i moraliskt hänseende såg misslyckanden $\mathrm{i}$ sitt eget liv. För många haltar dock den senare jämförelsen betänkligt genom att David därefter tydligt visade på en djup ånger och bad Gud om förlåtelse (jfr. exempelvis Psalt. 51). Några kristna ledare "profeterade" om en för Trump kommande valvinst 2020 och kom att hamna i mycket dålig dager efter fastställt valresultat. ${ }^{2}$

\section{Stark kritik}

I svensk media lyftes så gott som dagligen kritik fram mot Trump under dennes presidentperiod, men emellanåt även av de evangelikala eller "högerkristna" som röstat på honom. Ett problematiserat resonemang kring det stöd som så många miljoner amerikaner de facto gav uttryck för saknades ofta. Istället gavs inte sällan den förenklade förklaringen att dessa var lågutbildade och inskränka vita. Men det finns, skriver professor Mark S. Weiner (själv demokrat), en nordisk oförmåga att förstå varför "vanliga amerikaner" röstade på Trump, en "oförmåga att sätta sig in i andra människors situation" och att detta "är ett tecken på fundamental brist på föreställningsförmåga" (Kvartal, 18 nov. 2020). Att var femte högutbildad svart gav honom sin röst passade inte in $\mathrm{i}$ bilden, inte heller att en stor majoritet latinos/hispanics på Rio Grande-slätten i Texas röstade på honom, eller att Floridakubaner föredrog Trump före Biden. Stödet var helt enkelt stort bland många vanliga "nyamerikaner", men även bland månggenerationsamerikaner, inte minst bland de med kristen övertygelse i de centrala och södra delarna av landet.

Något som i Sverige rimligtvis borde ansetts som en positiv nyhet var att Trump införde 12 veckors betald föräldraledighet för federalt anställda och att 
han arbetat för att priset på både receptbelagda mediciner och sjukförsäkringar skulle sänkas, men sådana nyheter låg under den svenska journalistradarn.

Det finns naturligtvis goda skäl till en sakligt uttalad kritik av Trump - från såväl politisk som moralisk synvinkel. Det gäller såväl hans agerande som brist på agerade, hans uttalanden och ett exempellöst twittrande, med mer eller mindre väl genomtänkt innehåll. Inte minst i de demokratiska leden löpte skarp kritik som en röd tråd, inte minst företrädd av Nancy Pelosi, demokratisk talman i representanthuset. En första riksrättsprocess drogs igång under december månad 2019, men ledde ingen vart. Åtalet lades ner. Även ett andra åtal följde. I stort kan man konstatera att dessa juridiska processer i kongressen blev partipolitiserade. Men även från mer renodlat kristet håll kom kritik, också i Sverige. Ibland innefattades de "evangelikala" i denna. Den omnämnde Michael Horton skriver i Christianity Today att de evangelikala som stödjer Trump samtidigt stödjer "narcissism, greed, and deceitfulness in the pursuit of power". Horton talar om att Trumps tro inte är evangelikal utan i stället präglad av "moralistic, therapeutic deism" (MTD) och "pragmatism". I svenska Dagens Nyheter kunde vi läsa att den Trumpkritiske Pekka Mellergård, kristen skribent och neurokirurg, menade att Norman Vincent Peales tankar om att "attityder är viktigare än fakta", att ta kontroll över sin värld och att se sig själv som en som lyckats, satt tydliga spår hos Trump. Gwenda Blair, som skrivit flera böcker om Trump, talar om att Peale fått Trump att fastställa en bild av sig själv som vinnande. Titeln på en artikel av Blair talar för sig själv: "How Norman Vincent Peale taught Donald Trump to worship himself". Oavsett, kan vi fast- ställa att Peale satt en prägel på Trump och att Peales teologi ligger långt ifrån den lutherska "korskristendom" som under århundraden starkt betonats i Norden.

I en förklaringsmodell av det evangelikala stödet för Trump tog professorn i etik vid Enskilda Högskolan/Teologiska Högskolan i Stockholm, Susanne Wigorts Yngvesson, i en gästkrönika i Kyrkans tidning den 28 oktober 2020 upp den nämnda Kyros-parallellen, att evangelikala jämfört Trump med den i Bibeln omtalade kung Kyros. Hon skriver att så länge evangelikala anser att Trump skulle kunna vara eller ses som ett utvalt redskap och agerar på ett sätt som ligger i linje med vad Gud önskar, oavsett hur hans egen tro ser ut, räcker för att stödja honom. Att han "ljuger, förtalar, förtrycker och diskriminerar spelar ingen större roll för den stora saken. Att de har en president som ena stunden deltar i gudstjänst och nästa påstås beskriva tron som 'bullshit' spelar heller ingen roll”. Wigorts Yngvesson skriver även att de evangelikala kämpar hårt och med brutala medel men vad hon menar med detta framgår inte. I andra kommentarsfält kunde anhängare av Trump av etablerade svenska akademiker beskrivas i starkt värderande termer: "Tyvärr finns det gott om nötter som tror på hans lögner", skrev en teologiprofessor i Örebro på Facebook efter valet.

Bland de amerikanska evangelikala kritikerna av Trump återfinns Ed Stetzer, dekan och professor på Wheaton College. Han skriver till exempel att de evangelikala inte brukade sin "profetiska röst", inte talade "sanning" in i maktens korridorer (USA Today, 10 jan. 2021) Vidare har man inte tydligt nog begrundat "rasism, sexism, nationalism och en rad andra synder" som kommit upp till ytan inom de egna leden under Trumps tid 
men även tidigare. Bekännelsen till Jesus måste gå före tanken att behålla politisk makt.

Bland de pastorer som hade "profeterat" att Trump skulle vinna återfinns den välkände Pat Robertson - tv-profil, grundare till Regent University och tv-kanalen CBS och en gång själv presidentkandidat. Men Robertson kom efter den sista tidens händelseutveckling under Trumps presidentperiod att bli Trumpkritisk och kom, enligt egen utsago, fram till att Trump "lever i en alternativ verklighet" och tror att det han säger är sanning.

\section{3 november och 6 januari}

Coronaviruset anträdde landet och tog fart under den första delen av 2020. Trumps fråga om man kunde dricka något som renade organen/kroppen från viruset kunde ses upprepade gånger i svensk television; även uttalandet att han trodde att det hela snart skulle vara över. Han talade om flockimmunitet - som också vi gjorde i Sverige. Till pandemin, som alltmer kom att prägla den amerikanska befolkningen och den politiska scenen och som orsakade arbetslöshet och försämrad ekonomi, kom bilder på polisbrutalitet och en "Black-lives-matter"-rörelse, vilken Trump hanterade på ett sätt som hos många väckte vrede. Och mer var att vänta. Men valet såg fortfarande ut att kunna bli jämt, även om Biden ledde i opinionsmätningarna - många hade händelseutvecklingen från valet $2016 \mathrm{i}$ gott minne.

Onekligen trodde Trump ett tag under valnatten att han var på väg mot seger och senare att han rättmätigt hade vunnit "om valet inte hade varit riggat", om segern inte "stulits" från honom. Men inget hjälpte. Sifforna, folkets röstantal och sedan elektorsrösternas, räckte uppenbarligen inte till. Det märkliga är han ännu inte släppt tanken på att han egentligen segrade. Han som avskyr att förlora och av sin far fostrats till att bli en vinnare och som i allt tänker att han är en vinnare, förlorade. Att valförlusten inte erkändes av Trump och en rad andra ledde som bekant till att anhängare landet över protesterade mot det officiella valresultatet. Försök att på juridisk väg ändra resultatet ledde ingen vart, och Trumps brist på erkännande av valförlusten ledde knappast till att extravalet av senatorer i Georgia gick bättre än för honom själv: båda de republikaner som förväntats vinna förlorade, vilket ledde till det för republikanerna ödesdigra resultatet att partiet förlorade makten i US Senate. I representanthuset hade man vunnit ett antal platser, men inte tillräckligt många för att nå majoritet. Läget var dystert. "The China virus" härjade fortsatt och den demokratiska "vänstern" skulle nu ta över.

När det blev dags för den 6 januari hade många samlats i Washington DC för att fortsatt uttrycka sitt stöd för Trump. En del kristna fanns vid tiden på plats för en s.k. "Jerikomarsch", där man blåste i judiska zhofar-horn, likt en gång vid Jerikos murar. Men där fanns även mer våldsamt inriktade anhängare, ett antal tillhörde yttersta högern, "vit makt"grupper och grupper som färgats starkt av konspirationsteorier. I det tal Trump höll denna dag fanns det ett antal personer som uppfattade innehållet i detsamma som ett stöd för att fortsätta kampen och en åtgärd var då att attackera och "ta över" Kapitolium - och det för många oväntade inträffade. Människor tog sig med våld in i byggnaden och i tumultet hördes skottlossning; ledamöterna utrymde byggnaden, människor skadades och för några leddes det hela till döden. Bilder över våldsamheterna blandades med bilder över andra och lugnare protester och dessa sändes ut över världen. Bland 
plakaten kunde man se budskap som "God bless Trump" och "Jesus saves". Många valde att inte problematisera detta utan generaliserade i tongångar om att de kristna i USA är högerkristna och farliga. Man skiljde inte på våldsamma högerextrema personer, som även kunde skrika "kill Pence" och vanliga konservativa amerikaner, som ville visa sitt stöd för Trump. I samband med våldsamheterna kom snabbt kommentarer från många pastorer, även från den välkände Rick Warren, som kraftfullt tog avstånd till stormningen av Kapitolium och kallade den för "inhemsk terrorism". Även den socialkonservative teologen Russell Moore från Southen Baptist Convention var skarpt kritisk. Han är för övrigt ordförande i samfundets Etik och religionsfrihetskommission (ERLC). Om ni kan försvara det som skedde den 6 januari kan ni försvara allt, förklarade han kritiskt i TIME Magazine.

Trump ansågs genom sitt tal av många betraktare som anstiftare till händelseutvecklingen och det av demokraterna styrda representanthuset önskade åter ställa honom inför riksrätt - för "uppsåtlig anstiftande till uppror" - förmodligen mer som ett politiskt "statement" än i tro att han skulle fällas. En riksrättsprocess gäller, om vi ser till den ursprungliga ordalydelsen, ett eventuellt avsättande av presidenten (eller vicepresidenten eller andra "civil officers"), vilket Trump inte längre var under tiden för denna andra riksrättsprocess mot honom. ${ }^{3}$ Åtalet var i denna mening inte konstitutionellt sanktionerat. Alla höll inte med om att en ny riksrätts- process var icke-konstitutionell och i representanthuset röstade en majoritet (232 -197) för att Trump kunde ställas inför riksrätt. Bland majoriteten återfanns elva republikaner. Den 13 februari 2021 friades dock Trump av senaten. 57 senatorer röstade för en fällande dom (50 demokrater och 7 republikaner), 43 för ett friande (samtliga republikaner). För en fällande dom i senaten krävs kvalificerad majoritet. ${ }^{4}$

Onekligen är Trump fortsatt både älskad och hatad. En del av de beslut han tog under sin presidentperiod och som hyllades av många konservativa kristna har Biden redan ändrat på och i representanthuset har man precis beslutat att ta bort begrepp som far, mor, son och dotter och ändra dessa till könsneutrala ord. Bortom fyraårsperioden med Trump pågår en kulturkamp om vilken den amerikanska identiteten bör vara och vilken inspirationsgrund den bygger på. Emellanåt kommer den tydligt upp till ytan inom den politiska sfären. Vilken inverkan Trump - eller den så kallade "trumpismen" - i långa loppet kommer att få på det republikanska partiet eller på den amerikanska politiken får framtiden utvisa. Noteras kan att det republikanska partiprogrammet, som antogs inför 2016 års val, behölls inför valet 2020 - utan förändringar. Vilka politiska, juridiska och kulturella uttryck kulturkampen kommer att ta sig framöver är av intresse inte endast för amerikaner, utan även för oss $i$ Norden för det som sker i USA har snart därefter ofta bäring på situationen här hemma. 5 


\section{Noter}

${ }^{1}$ Detta stöd för Israel ökade dock i stort inte stödet bland de judiska hemmaväljarna. 2016 röstade $24 \%$ på Trump och $71 \%$ på Hillary Clinton; 2020 röstade $22 \%$ på Trump och $76 \%$ på Joe Biden.

2 En allmän artikel i Politico om detta fenomen och andra "profetior" om Trump återfinns via:

https://www.politico.com/news/magazine/2021/02/18/how-christian-prophets-give-credence-to-trumpselection-fantasies-469598 (2021-02-22).

${ }^{3}$ Konstitutionens andra artikel, sektion 4, fastställer följande: "The President, Vice President and all civil Officers of the United States, shall be removed from Office on Impeachment for, and Conviction of, Treason, Bribery, or other high Crimes and Misdemeanors."

${ }^{4}$ Detta var den fjärde gången en amerikansk president ställts inför riksrätt: Andrew Jackson 1868 för att han ansetts ha överskridit sina befogenheter, Bill Clinton i januari 1999 för lögn under ed (Lewinskyaffären), samt Trump i december 2019 för maktmissbruk och förhindrande av kongressens arbete (när det gällde Ukrainafrågan, dvs. om Trump pressat Ukrainas president Volodymyr Zelenskyi att starta en utredning som kunde misskreditera Joe Biden). Richard Nixon avgick 1974 innan den planerade riksrättsprocessen mot honom inletts.

5 Om religionens roll i Vita huset tas upp i artikelförfattarens bok Från Truman till Trump (Skellefteå: Artos, 2020). Häri ges även en bakgrundsförklaring till religionens starka roll i det amerikanska samhället i stort. 